Zbigniew Jerzy Przerembski

ORCID: 0000-0002-1871-8331

Uniwersytet Wrocławski

\title{
Przedstawienia muzyczne w ilustracjach zbiorów polskich pieśni ludowych wydanych w latach czterdziestych i pięćdziesiątych XX wieku
}

Abstrakt: Tematem artykułu są ryciny towarzyszące zapisom pieśni (melodii i tekstów słownych) w publikowanych zbiorach. Przedstawiają motywy sztuki ludowej, instrumenty, pojedynczych muzykantów czy kapele. Ilustracje, oprócz funkcji czysto dekoracyjnej, miały nawiązywać do ludowej tradycji muzycznej regionów, z których pochodziły zamieszczone w zbiorze pieśni czy melodie instrumentalne. Jednak częściej mają walory artystyczne niż merytoryczne. Zapewne plastycy ilustratorzy nie znali specyfiki regionalnej polskiego folkloru muzycznego, jego zróżnicowania pod tym względem. Nie znali też budowy przedstawianych przez siebie instrumentów, w znaczeniu: szczegółów budowy czy sposobu trzymania podczas gry lub też cechy te „twórczo” modyfikowali. $\mathrm{Z}$ tego zapewne powodu sceny muzyczne są ukazane tak, jak je artysta widział, patrząc przez pryzmat własnej osobowości artystycznej, nie zaś tak, jak w istocie wyglądały.

Słowa-klucze: publikowane zbiory pieśni i melodii ludowych, grafika, muzycy ludowi, instrumenty muzyczne

Co prawda nagrania muzyki ludowej zapoczątkowano w naszym kraju już na początku XX stulecia (chociaż nader skromnie - tylko dwa woskowe wałki fonograficzne Edisona), a w następnych latach dokonywano ich jeszcze z rzadka, i dopiero od lat trzydziestych przybrały one tak duży wymiar, że powstawały gromadzące je archiwa fonograficzne — głównie przy Bibliotece Narodowej w Warszawie i Uniwersytecie Poznańskim w Poznaniu (sporadycznie też innych instytucjach). W znacznej większości zbiory te nie przetrwały drugiej wojny światowej (zostały zniszczone, choć być może częściowo zaginęły) ${ }^{1}$. W tej sytuacji — jako

${ }^{1}$ Chodzi o nagrania dokonane w 1904 roku w Zakopanem przez Romana Zawilińskiego (2 wałki z zapisem oracji weselnej oraz przyśpiewek i pieśni w wykonaniu Jana Sabały), nagrania Willego Blossfelda z 1906 roku (14 wałków z pieśniami i muzyką górali podhalańskich), nagrania Paula Schmidta z 1911 (34 wałki z pieśniami i muzyką ludową mieszkańców Śląska Opolskiego) oraz 
że część wykonawców ludowych (śpiewaków, muzykantów) przeżyła wojnę postanowiono nagrać ich, jak też innych, ponownie. Służyła temu ogólnopolska Akcja Zbierania Folkloru Muzycznego prowadzona przez pracowników i współpracowników Państwowego Instytutu Sztuki (dziś Instytut Sztuki PAN) w latach 1950-1954. Plonem akcji, oprócz nagrań fonograficznych, były publikowane zbiory, w których zapisom pieśni (melodii i tekstów słownych) towarzyszyły ryciny przedstawiające motywy sztuki ludowej, instrumenty, pojedynczych muzykantów czy kapele.

Treści motywów muzycznych zależały od formatu wydawnictw - najmniejsze $\mathrm{z}$ nich były zdobione drobnymi rysunkami inspirowanymi sztuką ludową. W większych przedstawiano już także ludzkie postaci w różnych sytuacjach. Oprócz funkcji czysto dekoracyjnej ilustracje miały informować o ludowej tradycji muzycznej regionów, z których pochodziły zamieszczone w zbiorze pieśni czy melodie instrumentalne. Tak więc przedstawiały instrumenty, symbolizowały etnomuzyczne regiony Polski ( $w$ zbiorach zawierających pieśni z różnych regionów), a także nawiązywały do tekstów słownych, na przykład do grup pieśni wydzielonych w ramach klasyfikacji treściowo-funkcjonalnej, jak scena oczepinowa wprowadzająca do pieśni weselnych i rodzinnych czy ekspresyjne tańce przed przyśpiewkami i piosenkami tanecznymi ${ }^{2}$. Ryciny mogły też wiązać się z tekstami konkretnych pieśni.

Profesor Adolf Chybiński - wybitny muzykolog, obejmujący badaniami zarówno historię muzyki, jak i muzykę ludową, związany z uniwersytetami we Lwowie i w Poznaniu - na początku lat pięćdziesiątych XX wieku wydał dwa zbiory będące wyborem pieśni i melodii ludowych z różnych regionów Polski. Obydwa ozdobił graficznie Maciej Makarewicz ${ }^{3}$. Na okładce pierwszego, zatytułowanego Od Tatr do Bałtyku. Śpiewnik krajoznawczy $(1950)^{4}$, widzimy monument podobny do tak zwanego Światowida ze Zbrucza (na Podolu), kamien-

rejestracje fonograficzne Juliusza Zborowskiego w Nowym Targu (48 wałków z pieśniami i muzyką górali podhalańskich). W 1930 roku powstało Regionalne Archiwum Fonograficzne w Poznaniu, przy Katedrze Muzykologii tamtejszego uniwersytetu (do drugiej wojny światowej zgromadziło ponad 4000 nagrań na wałkach i płytach żelatynowych, głównie z Wielkopolski, Pomorza, Górnego Śląska, Pienin i Mazowsza). W 1934 roku założono Centralne Archiwum Fonograficzne przy Bibliotece Narodowej w Warszawie (do drugiej wojny światowej znalazły się w nim 4862 wałki i 42 płyty oraz odręczne zapisy tekstów słownych i muzycznych pieśni ludowych z różnych regionów kraju). Zob. J.P. Jackowski, Zachować dawne nagrania, Warszawa 2014, s. 45-95, 111-175, 182-224.

2 Pieśni ludu krakowskiego, oprac. W. Poźniak, Kraków 1956, okładka i rysunki A. Darkow (A. Darowski i A. Kowalski), s. 73. Wielkopolskie śpiewki ludowe, oprac. J. Sobieska, Kraków 1957, okładka i rysunki Maciej Makarewicz, s. 77.

${ }^{3}$ Maciej Makarewicz współpracował z Polskim Wydawnictwem Muzycznym od końca lat czterdziestych. Jak pisze Justyna Nowicka: „Studiował w latach trzydziestych u mistrzów Młodej Polski, być może stąd w jego twórczości obecne są nie tylko elementy baśniowe i fantastyczne, ale i katastroficzne" (J. Nowicka, Pole widzenia. Kilka uwag o projektowaniu graficznym w PWM-ie, [w:] eadem, 70 na 70. Projektowanie graficzne w PWM w latach 1945-2015, Kraków 2015, s. 12-13).

4 Od Tatr do Battyku, [cz. 1] Śpiewnik krajoznawczy, zest. A. Chybiński, Kraków 1950. 
nego posągu, być może z IX-X wieku, interpretowanego jako odwzorowanie osi kosmicznej $^{5}$ (il. 1). Na śpiewnikowej ilustracji ma on jednak tylko jedno oblicze, a wyobrażona na oryginale posągu (między innymi) słowiańska bogini Mokosz z rogiem została zredukowana właściwie do samego jej atrybutu — rogu. Na postumencie wspiera się dziwnego kształtu trzystrunowa (sic!) harfa.

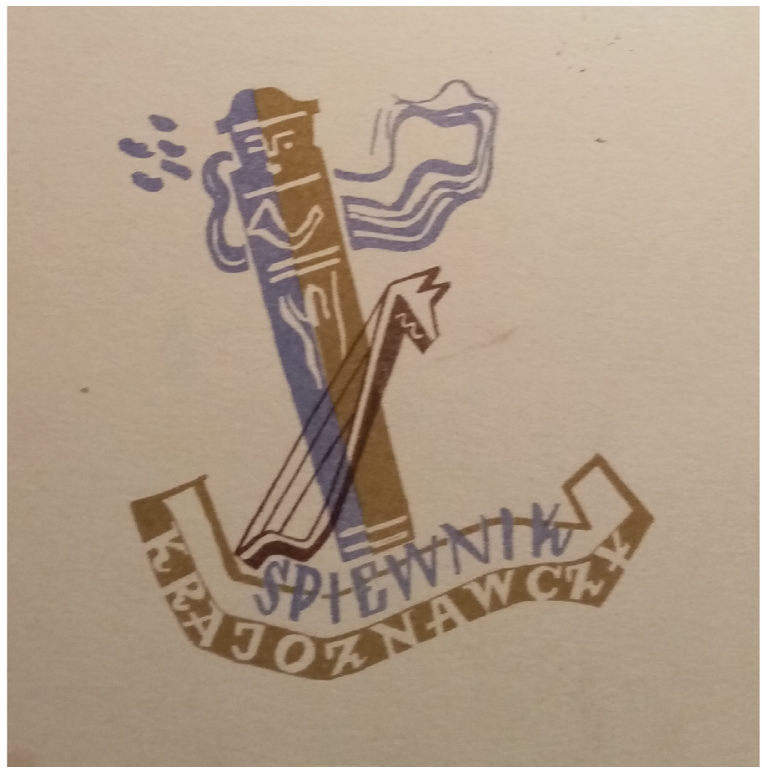

Ilustracja 1. Od Tatr do Bałtyku. Śpiewnik krajoznawczy, zest. Adolf Chybiński, Kraków 1950, okładka i ozdobniki Maciej Makarewicz (okładka)

Źródło: zbiory własne, fot. Z.J. Przerembski.

Skąd jednak to ikonograficzne nawiązanie do tak odległych, prehistorycznych czasów? Trzeba tu też przypomnieć, że gdy w 1802 roku ksiądz Hugo Kołłątaj formułował tezy szeroko pojętych badań historycznych, obejmujących także studia kulturoznawcze i ludoznawcze, postulował traktowanie źródeł folklorystycznych jako historycznych. Pisał wszak: „Chcąc atoli szukać w obyczaiach naszych wiadomości o tradycyach początkowych i podobieństwa do dawnych ludów, trzeba nam poznać obyczaie pospólstwa we wszystkich prowincyach, woiewodztwach i powiatach”. Należy zatem uzyskać i wykorzystać wiadomości „o zabawach pospólstwa, stosownie do części roku, o ich muzyce, o instrumentach muzycznych, o godach rocznych, czyli Saturnaliach naszego ludu, o Bachanaliach, o pieśniach wesołych, pasterskich, żałobnych, historycznych i tych, które dzieciom przy kolebkach śpiewają, o baykach i historyach" ${ }^{\circ}$.

\footnotetext{
5 Zob. J. Strzelczyk, Mity, podania i wierzenia dawnych Stowian, Poznań 2007, s. 206.

${ }^{6}$ H. Kołłątaj, List H. K. do T. M. z Otomuńca dnia 15. Lipca 1802 r. pisany, „Pamiętnik Warszawski" 2, 1810, nr 4, s. 38-40.
} 
Być może zatem wskazywane tu śpiewnikowe wyobrażenia plastyczne mają sugerować przedchrześcijańskie korzenie polskich pieśni ludowych. „Skamieliny" $\mathrm{z}$ tak odległych czasów trudno jednak w nich znaleźć, zwłaszcza w tekstach muzycznych, nieco łatwiej w słownych, czego przykładem zdaje się zawołanie: „Łado” w obrzędowych pieśniach weselnych. Łada według niektórych badaczy to imię słowiańskiej bogini miłości i urodzaju. Wracając jednak do ryciny z okładki — ani róg, ani harfa nie wiążą się $\mathrm{w}$ polskim folklorze $\mathrm{z}$ repertuarem pieśniowym, ten drugi instrument zresztą w ogóle w polskiej kulturze tradycyjnej nie występuje ${ }^{7}$.

Okładkę drugiego ze zbiorów opracowanych przez Chybińskiego, o tytule Od Tatr do Battyku. Lud polski gra $(1951)^{8}$, zdobi wizerunek kapeli w stylizowanych strojach ludowych, złożonej z dudziarza, skrzypka i basisty (il. 2). Zastrzeżenia budzi przede wszystkim postać dudziarza. Gra on bowiem na dudach podhalańskich, na co wskazują piszczałki - krótka melodyczna, bez roztrąbu, stosunkowo szeroka (mieści bowiem w środku trzy kanały) i długa burdonowa z prostym hiperbolicznym roztrąbem (podobnym do klarnetowego). Muzykant ten nie ma jednak na sobie stroju podhalańskiego, ponadto gra wspólnie ze skrzypkiem i basistą — nie jest to skład instrumentalny typowy dla Podhala ani dla żadnego innego regionu Polski. Równie nieprawdopodobne jest wyobrażenie na ostatniej stronie tomu dwuosobowej kapeli złożonej z górala grającego na podhalańskich dudach i skrzypka w sukmanie, być może Kaszuby (il. 3). Pierwszy stoi na tle gór, drugi morza, co zapewne ma być nawiązaniem do tytułu zbioru: Od Tatr do Battyku.

Na początku wspomnianej pierwszej, pieśniowej, części zbioru Chybińskiego znajdziemy wyobrażenie karpackiego zbójnika, o czym świadczy jego nakrycie głowy i strzelba u boku, grającego na dudach żywieckich, z wygiętymi łukowo konicznymi roztrąbami (il. 4). Przypomina nieco jedną z postaci umieszczanych na popularnych na Podhalu obrazach na szkle i drzeworytach należących do ikonograficznego wątku „Przyjęcie Surowca” (przedstawiającego próbę fizyczną kandydata do „towarzystwa” zbójeckiego, zwanego między innymi Surowcem) ${ }^{9}$. Ukazanie instrumentalisty może dziwić w śpiewniku, chociaż w naszym kraju na ogół grano melodie pieśni. Trudno jednak stwierdzić, czy grafik to wiedział i tym się kierował, wykonując ilustrację.

7 Rogi i trąby znalazły zastosowanie w szerzej pojętej strefie dźwiękowej tradycyjnej kultury — jako instrumenty sygnałowe, ale też wykorzystywane podczas czynienia tak zwanej obrzędowej wrzawy, realizowania antymuzyki, zob. L. Bielawski, Tradycje ludowe w kulturze muzycznej, Warszawa 1999, s. 119-120, 122; L. Bielawski, A. Mioduchowska, Kaszuby, cz. 1. Pieśni obrzędowe (Polska pieśń i muzyka ludowa: źródła i materiaty), red. L. Bielawski, t. 2, Warszawa 1997, s. 80; Z.J. Przerembski, O sygnałowych funkcjach ludowych instrumentów muzycznych, [w:] Instrumenty muzyczne w tradycji ludowej i folkowej, red. Z.J. Przerembski, Zakopane 2011, s. 125-128; idem, The muzykant as a product of nature and of culture, „Interdisciplinary Studies in Musicology” 8, 2009, s. 134-136; idem, Antymuzyka i antyinstrumenty w tradycji kulturowej ziem polskich, „Muzyka" 2021, nr 2, s. 121-140.

8 Od Tatr do Bałtyku, [cz. 2] Lud polski gra, zest. A. Chybiński, Kraków 1951.

9 Zob. Z.J. Przerembski, Dudy: instrument mało znany polskim ludoznawcom, Warszawa 2007, s. $183-187$. 


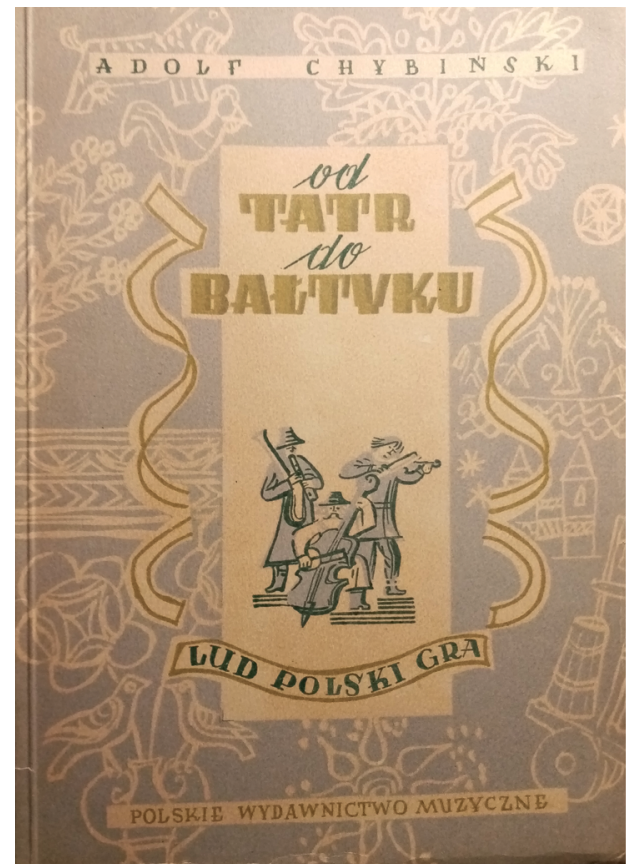

Ilustracja 2. Od Tatr do Bałtyku. Lud polski gra, zest. Adolf Chybiński, Kraków 1951, okładka i ozdobniki Maciej Makarewicz (okładka)

Źródło: zbiory własne, fot. Z.J. Przerembski.

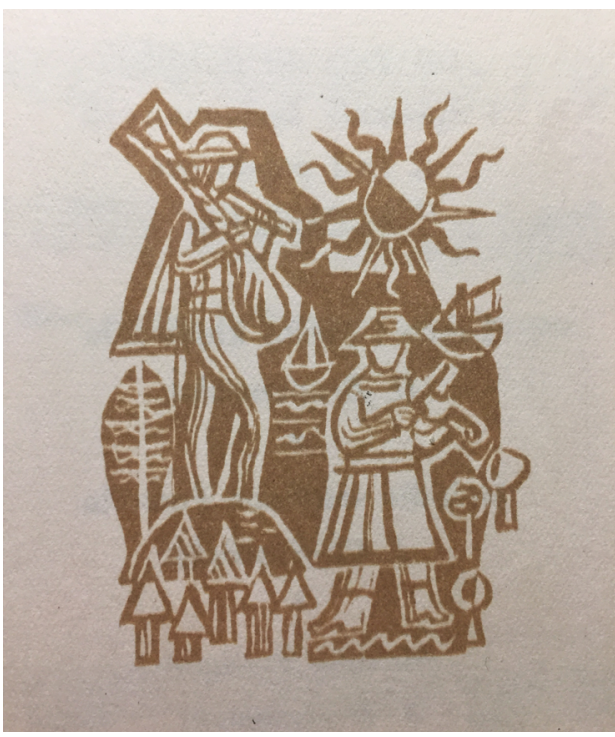

Ilustracja 3. Od Tatr do Battyku. Lud polski gra, zest. Adolf Chybiński, Kraków 1951, okładka i ozdobniki Maciej Makarewicz, s. 100

Źródło: zbiory własne, fot. Z.J. Przerembski. 


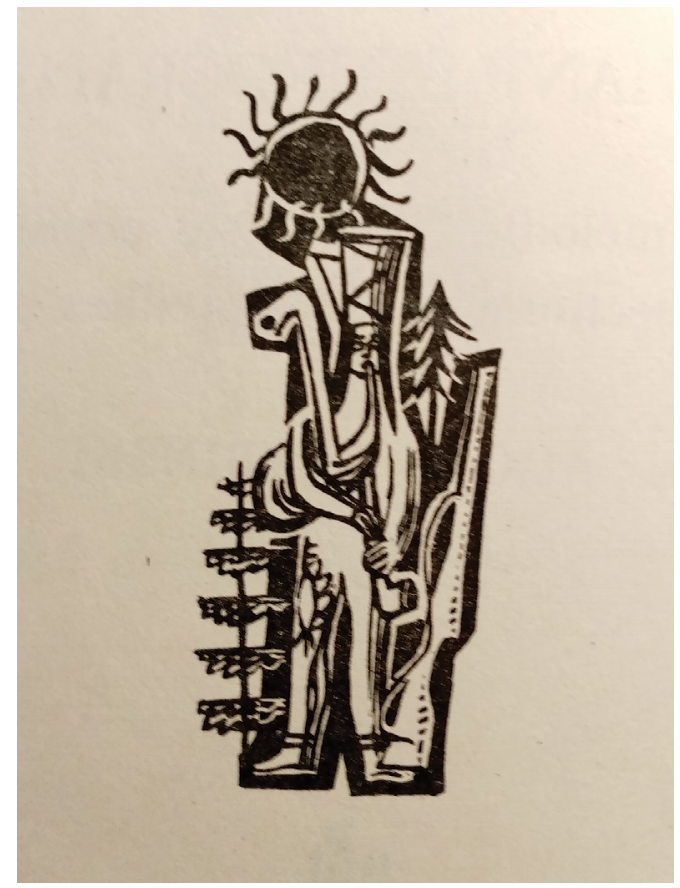

Ilustracja 4. Od Tatr do Battyku. Śpiewnik krajoznawczy, zest. Adolf Chybiński, Kraków 1950, okładka i ozdobniki Maciej Makarewicz, s. 6

Źródło: zbiory własne, fot. Z.J. Przerembski.

W obydwu tomach zbioru Od Tatr do Battyku grupy melodii z poszczególnych regionów zapowiadają motywy graficzne dosyć luźno lub nawet wcale niezwiązane z tymi regionami. Do wyjątków należy motyw wycinanki kurpiowskiej w formie lelui - Drzewa Życia, sygnalizującej melodie z Mazowsza Polnego, Leśnego i Starego (Kurpie), czy ryba w motywie wprowadzającym do melodii z Pomorza (Kaszub).

Rysunek muzykanta grającego na wielkopolskim „koźle weselnym”, największym z polskich rodzajów dud, autorstwa Andrzeja Darkowa ${ }^{10}$, zdobi okładkę i stronę tytułową zbioru Szlakiem kozła lubuskiego, opracowanego przez Jadwigę i Mariana Sobieskich (1954) ${ }^{11}$ (il. 5). Obydwa te przedstawienia nie budzą zastrzeżeń, mimo syntetyczności ukazują istotne cechy instrumentu: zbiornik powietrza z całej, nierozciętej skóry z pozostawionym włosiem, mieszek do jego nadymania, piszczałkę melodyczną $\mathrm{z}$,kozią główką” i wygiętym łukowo dźwięcznikiem, oraz burdonową, dwukrotnie załamaną pod kątem $180^{\circ}$ i także zakończoną roztrąbem, a nawet łańcuszki przy obydwu tych piszczałkach.

10 Pod pseudonimem Darkow skrywało się dwóch grafików związanych z Polskim Wydawnictwem Muzycznym: Andrzej Darowski i Andrzej Kowalski, zob. J. Nowicka, Pole widzenia, s. 13.

11 Szlakiem kozła lubuskiego, zebr. i oprac. J. i M. Sobiescy, Kraków 1954, okładka i rysunki A. Darkow (A. Darowski i A. Kowalski). 


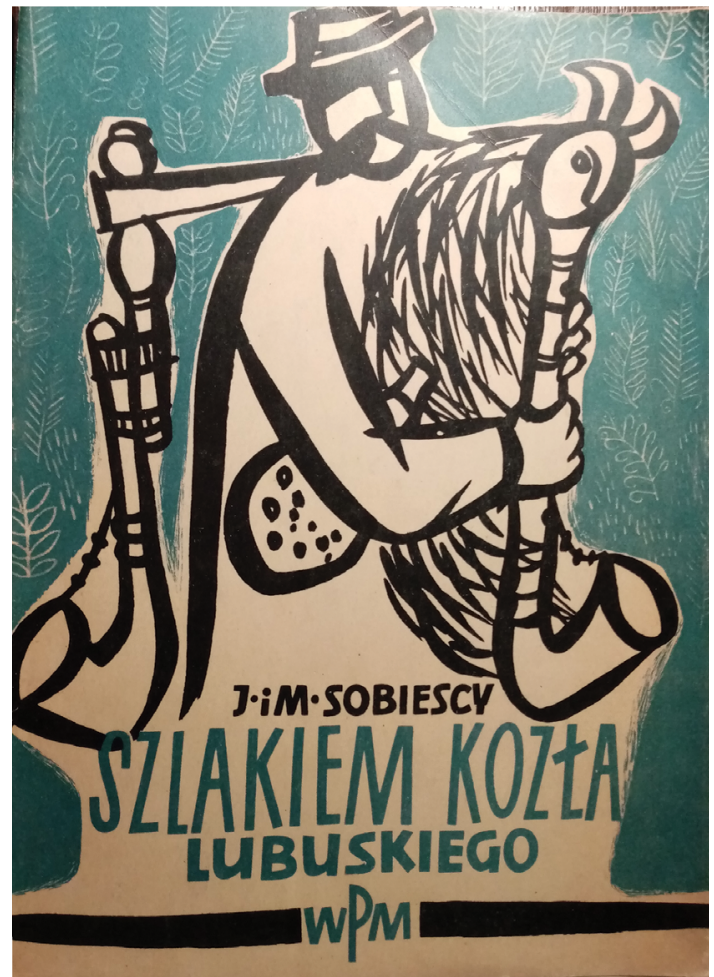

Ilustracja 5. Szlakiem kozła lubuskiego, zebr. i oprac. Jadwiga i Marian Sobiescy, Kraków 1954, okładka i rysunki A. Darkow [Andrzej Darowski i Andrzej Kowalski] (okładka)

Źródło: zbiory własne, fot. Z.J. Przerembski.

Wizerunki „koźlarza” czy skrzypka jeszcze niejednokrotnie pojawiają się na kartach tego zbioru, oddzielnie bądź razem (grali bowiem wspólnie w tradycyjnej zachodniowielkopolskiej kapeli). Nie brakuje nawet „koźlarza” przedstawionego w towarzystwie kóz, dostarczycielek skór na dudowe zbiorniki powietrza.

Zapewne poświęcenie zbioru głównemu instrumentowi zachodniowielkopolskiego regionu, nazwanemu właśnie od tego instrumentu Regionem Kozła (co niespotykane nie tylko w Polsce, lecz także w Europie), wymogło staranność także w plastycznych ilustracjach. Jednak nie do końca. Oto na jednej z ilustracji widzimy kapelę z innych stron — złożoną ze skrzypka i muzykanta grającego na „marynie”, rodzaju basów, hybrydzie chordofonu i idiofonu (talerzyki na pręcie w główce), typowego dla Szamotulskiego, Pałuk i Kujaw. Pełny już skład kapeli z tych regionów, a więc oprócz skrzypiec i ,maryny” także klarnet, przedstawiono na innej stronie tegoż zbioru. Nie zabrakło muzykanta grającego na samej „marynie”, co zupełnie nietypowe dla ludowej praktyki instrumentalnej (il. 6). Kilkukrotne przedstawienie „maryny” zdaje się świadczyć, że nie mamy tu do czynienia z przypadkowym błędem, lecz raczej z niekompetencją etnomuzykologiczną grafika. 


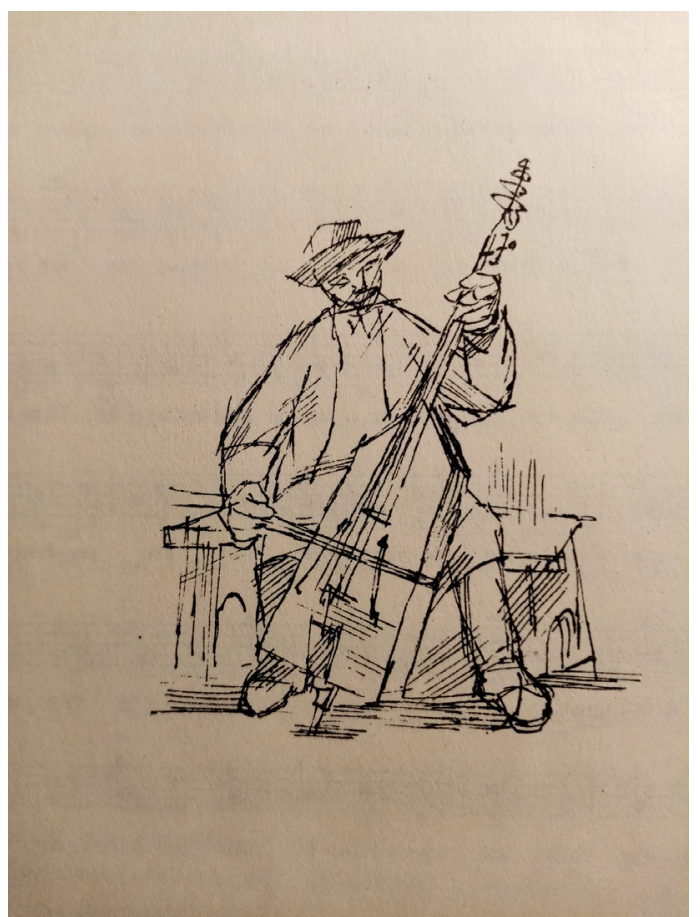

Ilustracja 6. Szlakiem kozła lubuskiego, zebr. i oprac. Jadwiga i Marian Sobiescy, Kraków 1954, okładka i rysunki A. Darkow [Andrzej Darowski i Andrzej Kowalski], s. 78

Źródło: zbiory własne, fot. Z.J. Przerembski.

Trzyosobową kapelę złożoną ze skrzypiec, basów i piszczałki możemy zobaczyć na rysunku Andrzeja Darkowa w Pieśniach ludu krakowskiego, zredagowanych przez Włodzimierza Poźniaka $(1956)^{12}$. Właśnie piszczałka budzi zastrzeżenia — ze względu na nietypowy, duży, koniczny roztrąb. W naszym kraju samodzielne ludowe piszczałki (niebędące częścią złożonego instrumentu, na przykład dud) nie mają bowiem roztrąbów, są ponadto instrumentami głównie pasterskimi i nie wchodzą w skład kapel. Na piszczałce, pod samotną wierzbą, na podkrakowskim polu gra bosonogi mężczyzna, raczej nietradycyjnie ubrany, bo w ,chińskim” kapeluszu i w spodniach sztuczkowych na szelkach (il. 7). Piszczałka ma koniczny profil, nietypowy w polskim instrumentarium ludowym, chyba że jest skręcona spiralnie z płata kory wierzbowej - tego rodzaju instrumenty robiono sezonowo, na wiosnę, były nietrwałe (szybko się rozsychały).

12 Pieśni ludu krakowskiego. 


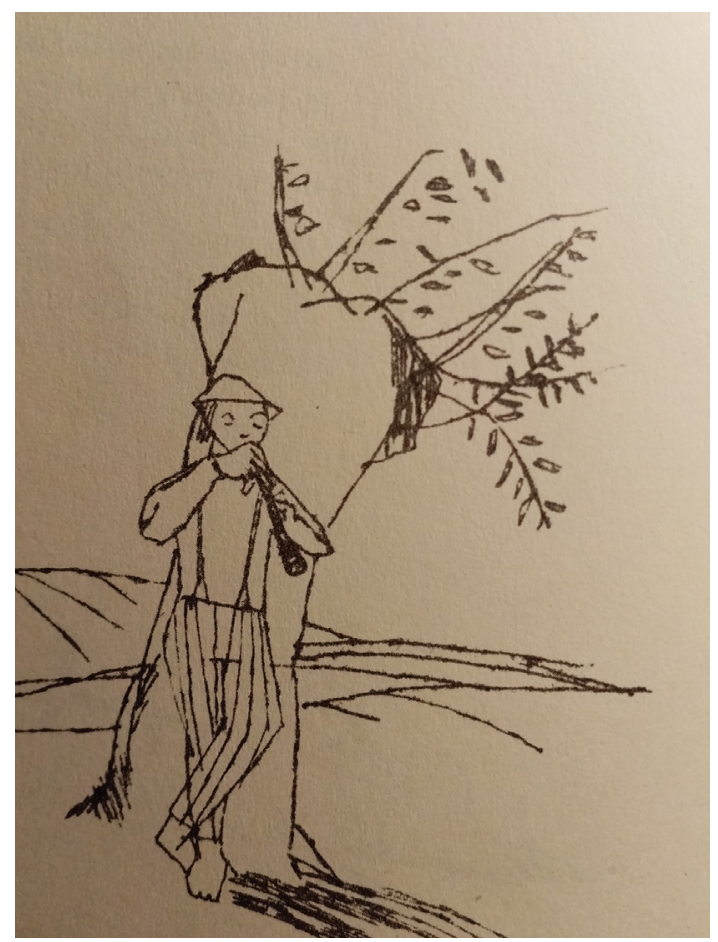

Ilustracja 7. Włodzimierz Poźniak, Pieśni ludu krakowskiego, PWM, Kraków 1956, okładka i rysunki A. Darkow [Andrzej Darowski i Andrzej Kowalski], s. 36

Źródło: zbiory własne, fot. Z.J. Przerembski.

Na ogół poprawne, chociaż ogólnie tylko przedstawione wizerunki muzykantów i instrumentów autorstwa Jerzego Karolaka zawiera zbiór Pieśni i tańce kujawskie, zebrane przez Urszulę Brzozowską (1950) ${ }^{13}$. W miarę realistycznie ukazana została scena pary tańczącej (jednak w nietypowym ujęciu za ręce) do gry pojedynczego skrzypka przed krytą strzechą chatą z podcieniem i siedzącym na ławie mężczyzną ${ }^{14}$. W praktyce ludowej naszego kraju na „,zwykłych”, to znaczy nieweselnych, zabawach tanecznych bawiono się często do muzyki jednego tylko muzykanta. Zresztą i podczas tak zwanych biednych wesel, u niezamożnych włościan, niemogących sobie pozwolić na wynajęcie kapeli, nierzadko grywali pojedynczy muzykanci - na ogół skrzypkowie, przynoszący z sobą „,statki”, czyli instrumenty akompaniujące, jak basy czy bębny (zazwyczaj mniejsze, jednomembranowe), na których grali, na zmianę, mający poczucie rytmu goście weselni.

13 Pieśni i tańce kujawskie, zebr. U. Brzozowska, Kraków 1950, okładka H. Tomaszewski, ozdobniki J. Karolak.

14 Ibidem, s. 23. 
W zbiorze tym nie budzą większych zastrzeżeń ozdobniki przedstawiające grającego skrzypka czy same skrzypce o ludowych formach korpusu ${ }^{15}$. Nie do końca jednak można to powiedzieć o muzykancie dmącym w piszczałkę, która jest za długa, a ręce zakrywające na niej otwory palcowe zbyt daleko jedna od drugiej — powinny być obok siebie, jako że palce zakrywają lub odkrywają kolejne otwory ${ }^{16}$. Z kolei wizerunek samej piszczałki ma nietypową liczbę (osiem) otworów palcowych ${ }^{17}$ oraz niespotykany w samodzielnych ludowych piszczałkach hiperboliczny roztrąb. We wlocie kanału piszczałki można też dostrzec stroik (trudno stwierdzić, czy pojedynczy, czy podwójny), zatem ma to być piszczałka stroikowa, w takiej postaci też nietypowa, przypominająca klarnet (który jednak ma system klapowy).

Wizerunek podhalańskich złóbcoków, na tle różnych elementów z naturalnego i kulturowego pejzażu Podhala i Tatr (w tym Chrystusa Frasobliwego i zbójnika tańczącego z pistoletem i ciupagą), zdobi drugie, powojenne wydanie zbioru Muzyka Podhala zebranego przez Stanisława Mierczyńskiego (1949) ${ }^{18}$. Okładkę zaprojektował Maciej Makarewicz, który prawdopodobnie wykorzystał w niej rysunek złóbcoków Stanisława Witkiewicza ilustrujący (obok innych instrumentów — tablica 64 Narzędzia gędziebne) pracę Władysława Matlakowskiego Zdobienie $i$ sprzęt ludu polskiego na Podhalu. Zarysy życia ludowego (1901) ${ }^{19}$.

Rozpatrywane tu pod względem ilustracji graficznych zbiory pieśni i muzyki ludowej ukazały się w latach czterdziestych i pięćdziesiątych. W tamtym czasie działała w Polsce głównie jedna specjalistyczna oficyna: Polskie Wydawnictwo Muzyczne w Krakowie. Było z nią związanych niewielu plastyków ilustratorów. W latach późniejszych w wydawnictwie tym odstąpiono od graficznego ilustrowania zbiorów folklorystycznych, częściowo zastępowanego fotografiami. Niekiedy łączono zdjęcia z rycinami, wykorzystując prace innych autorów. W dokonanym przez Aleksandrę Szurmiak-Bogucką wyborze „śpiewek” i „nut” podhalańskich Górole, górole, góralsko muzyka: śpiewki Podhala $(1959)^{20}$, opracowanym gra-

15 Ibidem, s. 2, 19.

16 Ibidem, s. 13.

17 Ibidem, s. 40. Na przykład w Beskidach (Śląskim i Żywieckim) piszczałki ośmiootworowe wytwarzał tylko Franciszek Szczotka z Milówki, później z Kiczyc (koło Skoczowa), a zachowały się jedynie dwa ich egzemplarze, zob. A. Kopoczek, Instrumenty muzyczne Beskidu Śląskiego i Żywieckiego. Aerofony proste i ich repertuar, przedm. A. Dygacz, Bielsko-Biała 1984, s. 81-82.

18 Muzyka Podhala = La musique du Podhale, zebr. i ułożył S. Mierczyński, przedm. K. Szymanowski, Kraków 1949; proj. okładki M. Makarewicz. Pierwsze wydanie ukazało się w Lwowie w 1930 roku. Zdobią je ilustracje Zofii Stryjeńskiej.

19 W. Matlakowski, Zdobienie i sprzęt ludu polskiego na Podhalu. Zarys życia ludowego, Warszawa 1901, tabl. 64, zob. Polona, https://polona.pl/item/zdobienie-i-sprzet-ludu-polskiego-na-pod halu-zarys-zycia-ludowego,MzEzNDk4NTI/8/\#info:metadata (dostęp 30.07.2021).

20 Górole, górole, góralsko muzyka: śpiewki Podhala, wyb. melodii i tekstów A. Szurmiak-Bogucka, red. W. Dulęba, oprac. graf. B. Brzozowska, fot. K. Gazdowska, Z. Kamykowski, W. Werner, Kraków 1950. 
ficznie przez Barbarę Brzozowską, znajdziemy liczne fotografie, w tym góralskich muzykantów i instrumentów. Są także zdjęcia ludowych rzeźb przedstawiających muzykantów - jednego z piszczałką (podobnie jak we wskazywanych wcześniej rysunkach dłonie ,piszczka” znajdują się zbyt daleko od siebie) i jednego dudziarza (jednak z niepodhalańskim, raczej żywieckim rodzajem dud i dłońmi całkowicie już nieprawidłowo ułożonymi na dudowej piszczałce melodycznej — tuż przy jej wlocie) $)^{21}$. Zbiór ten zdobią też fragmenty wspomnianego tradycyjnego wątku ikonograficznego Przyjęcie Surowca - przechodzącego próbę kandydata na zbójnika, i przygrywającego w tym czasie zbójnickiemu „towarzystwu” dudziarza $^{22}$. Całą scenę zamieszczono na okładce monografii Włodzimierza Kotońskiego Góralski i Zbójnicki. Tańce górali podhalańskich, projektu Jana Kurkiewicza $(1956)^{23}$. Trzeba jednak pamiętać, że wątek ten jest proweniencji słowackiej, jeśli nie węgierskiej, co odnosi się także do instrumentu dudziarza — podobnie jak we wzmiankowanych dudach z rzeźby i tu dudy są niepodhalańskie, zapewne słowackie (il. 8) ${ }^{24}$. W zbiorze Górole, górole, góralsko muzyka znajduje się też rycina Walerego Eljasza-Radzikowskiego z 1892 roku przedstawiająca znanego góralskiego przewodnika tatrzańskiego (towarzysza wypraw górskich „króla Tatr” Tytusa Chałubińskiego), gawędziarza (zwanego nawet „Homerem Podhala”), „polowaca" i muzykanta - Jana Krzeptowskiego Sabałę z złóbcokami ${ }^{25}$. Tu wyobrażenie jest realistyczne i całkowicie poprawne.

Umieszczane w zbiorach pieśni, w odniesieniu do folkloru podhalańskiego, wspomniane motywy ikonograficzne słowackiego (węgierskiego) pochodzenia, w tym słowackiego rodzaju dud, wpisują się w jakimś stopniu w koncepcję tradycji wynalezionej Erica Hobsbawma. Podobnie jak fenomen dużej popularności w podhalańskim folklorze słowackiego przecież „harnasia” Janosika, który nigdy nie był po północnej stronie Tatr, a i ,zbójował” niecałe dwa lata (1711-1713). Trzeba tu zauważyć, że pieśń i muzyka ludowa górali podhalańskich w swej współczesnej postaci została w pewnej mierze „wynaleziona” przez warszawskich i krakowskich inteligentów odwiedzających Tatry i Zakopane (a stopniowo też inne podhalańskie miejscowości) od ostatniej ćwierci XIX wieku. Słynny dr Chałubiński - popularyzator nie tylko tatrzańskiej natury, lecz także podhalańskiej kultury — organizował dla nich góralskie ,posiady” z ludową muzyką

21 Ibidem, s. 2, 37. Nie można jednak wykluczyć, że tego rodzaju dud używano też dawniej na Podhalu, zwłaszcza Niżnym, zob. Z.J. Przerembski, Do typologii i historii instrumentów dudowych polskich Karpat, [w:] Szlakiem karpackich tradycji ludowych, red. B. Lewandowska, Kraków 2012, s. 16-20.

22 Górole, górole, góralsko muzyka, s. 21, 63.

23 W. Kotoński, Góralski i Zbójnicki. Tańce górali podhalańskich, Kraków 1956, proj. okładki J. Kurkiewicz.

24 Zob. Z.J. Przerembski, Dudy: instrument mało znany polskim ludoznawcom, s. 183-187.

25 A. Szurmiak-Bogucka, op. cit., s. 9. Ta sama ilustracja zob. http://pinakoteka.zascianek.pl/ Eljasz_Radzikowski/Images/Sabala.jpg (dostęp: 30.07.2021). 
i tańcami. Wówczas to „Panowie” zapoczątkowali proces wybiórczego ograniczenia tradycji przez ograniczanie w repertuarze góralskim pieśni (a w zasadzie ich wariantów) zbieżnych z ogólnopolskim zasobem repertuarowym, na korzyść odbiegających od niego stylistycznie ukształtowań uznanych za dawne i ,typowo" podhalańskie, a ukształtowanych w istocie przez wpływy słowackie (co typowe na pograniczu kulturowym). W rezultacie ten ,wynaleziony” folklor muzyczny Podhala jest nienaturalnie ograniczony ilościowo oraz jednolity formalnie i stylistycznie (głównie melodyczny styl descendentalny, prawie wyłącznie dwumiarowe ukształtowanie metrorytmiczne, głównie krótkie, przyśpiewkowe formy pieśniowe o stosunkowo jednolitych formatach wersyfikacyjnych, niewielka liczba wątków muzycznych). Wykazuje też niewielkie podobieństwo do folkloru innych regionów Polski, duże zaś do słowackiego ${ }^{26}$. Nawiasem mówiąc, powoduje to znaczną rozpoznawalność podtatrzańskich „nut” przez nierozeznanych nawet w polskiej muzyce ludowej słuchaczy.

Podsumowując, można stwierdzić, że ilustracje zbiorów pieśni ludowych z lat czterdziestych i pięćdziesiątych XX wieku częściej mają walory artystyczne niż merytoryczne. Zapewne plastycy nie znali specyfiki regionalnej polskiego folkloru muzycznego, jego zróżnicowania pod tym względem. Świadomość, że „,co wieś to inna pieśń", nie była powszechna. Zabrakło konsultacji etnomuzykologicznych. Być może ilustratorzy zbiorów nie znali dokładnie budowy przedstawianych przez siebie instrumentów, w znaczeniu: szczegółów budowy czy sposobu trzymania podczas gry, lub też je „twórczo” modyfikowali i dlatego sceny muzyczne są ukazane tak, jak je artysta widział - przez pryzmat własnej osobowości artystycznej, nie zaś tak, jak w istocie wyglądały. Przewaga czynników subiektywnych nad obiektywnymi pojawia się w ikonografii muzycznej już pod koniec XIX wieku i nasila w następnym stuleciu. $Z$ większym realizmem pod tym względem spotykamy się głównie w sztuce staropolskiej.

26 Z.J. Przerembski, O fenomenie muzyki góralskiej na Podhalu, „,Rocznik Podhalański” 14, 2019, s. $316-321$. 

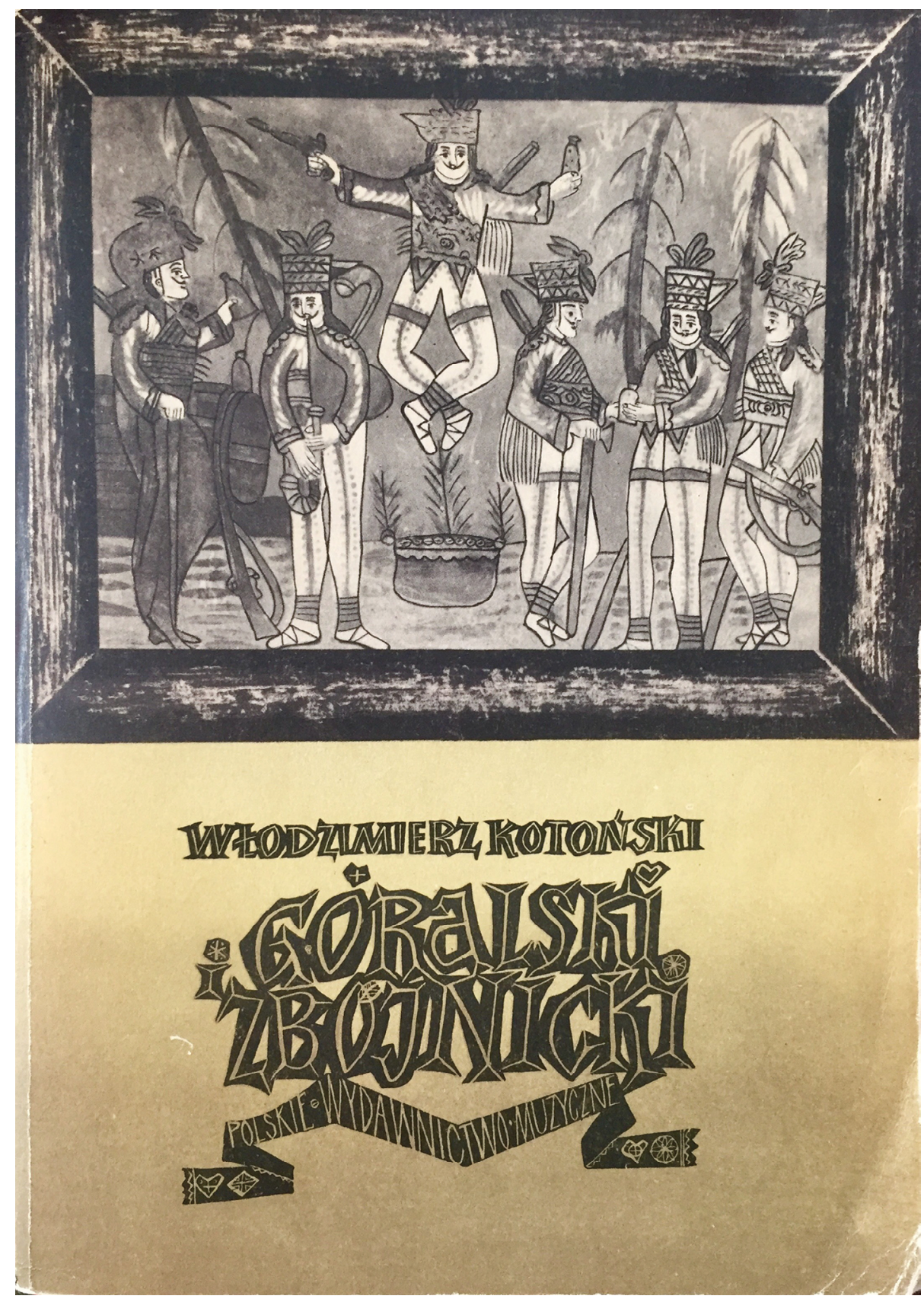

Ilustracja 8. Włodzimierz Kotoński, Góralski i Zbójnicki. Tańce górali podhalańskich, Kraków 1956, proj. okładki Jan Kurkiewicz (okładka)

Źródło: zbiory własne, fot. Z.J. Przerembski. 


\title{
Musical performances in the illustrations of the collections of Polish folk songs published in the 1940s and 1950s
}

\begin{abstract}
The subject of the article are figures accompanying the songs (melodies and verbal texts) in the published collections. They present folk art motifs, instruments, individual musicians or bands. The illustrations, in addition to their purely decorative function, were to refer to the folk music tradition of the regions from which the songs or instrumental melodies contained in the collection came from. However, they are more artistic than substantive. Probably the illustrators did not know the regional specificity of Polish musical folklore, its diversity in this respect. They also did not know the structure of the presented instruments, in the sense of: construction details or the way they were held while playing, or they "creatively" modified these features. Probably for this reason, the music scenes are shown as the artist saw them through the prism of his own artistic personality, and not as they actually looked.
\end{abstract}

Keywords: published collections of folk songs and melodies, graphics, folk musicians, musical instruments

\section{Bibliografia}

Bielawski L., Tradycje ludowe w kulturze muzycznej, Warszawa 1999.

Bielawski L., Mioduchowska A., Kaszuby, cz. 1. Pieśni obrzędowe (Polska pieśń i muzyka ludowa: źródła i materiały), red. L. Bielawski, t. 2, Warszawa 1997.

Górole, górole, góralsko muzyka: śpiewki Podhala, wyb. melodii i tekstów A. Szurmiak-Bogucka, red. W. Dulęba, Kraków 1950.

Hobsbawm E., Wprowadzenie. Wynajdywanie tradycji, [w:] E. Hobsbawm, T. Ranger, Tradycja wynaleziona, Kraków 2008, s. 9-23.

Jackowski J.P., Zachować dawne nagrania, Warszawa 2014.

Kołłątaj H., List H. K. do T. M. z Otomuńca dnia 15. Lipca 1802 r. pisany, „Pamiętnik Warszawski” 2, 1810, nr 4, s. 27-42.

Kopoczek A., Instrumenty muzyczne Beskidu Śląskiego i Żywieckiego. Aerofony proste i ich repertuar, przedm. A. Dygacz, Bielsko-Biała 1984.

Matlakowski W., Zdobienie i sprzęt ludu polskiego na Podhalu. Zarysy życia ludowego, Warszawa 1901, tabl. 64, https://polona.pl/item/zdobienie-i-sprzet-ludu-polskiego-na-podhalu-zarys-zycia-ludowego,MzEzNDk4NTI/8/\#info:metadata (dostęp 30.07.2021).

Muzyka Podhala = La musique du Podhale, zebrał i ułożył S. Mierczyński, przedm. K. Szymanowski, Kraków 1949.

Nowicka J., Pole widzenia. Kilka uwag o projektowaniu graficznym w PWM-ie, [w:] eadem, 70 na 70. Projektowanie graficzne w PWM w latach 1945-2015, Kraków 2015.

Od Tatr do Bałtyku, [cz. 1] Śpiewnik krajoznawczy, zest. A. Chybiński, Kraków 1950.

Od Tatr do Bałtyku, [cz. 2] Lud polski gra, zest. A. Chybiński, Kraków 1951.

Pieśni i tańce kujawskie, zebr. U. Brzozowska, Kraków 1950.

Pieśni ludu krakowskiego, oprac. W. Poźniak, Kraków 1956. 
Przerembski Z.J., Antymuzyka i antyinstrumenty w tradycji kulturowej ziem polskich, „Muzyka” 2021, nr 2, s. 121-140.

Przerembski Z.J., Do typologii i historii instrumentów dudowych polskich Karpat, [w:] Szlakiem karpackich tradycji ludowych, red. B. Lewandowska, Kraków 2012, s. 11-27.

Przerembski Z.J., Dudy: instrument mało znany polskim ludoznawcom, Warszawa 2007.

Przerembski Z.J., The muzykant as a product of nature and of culture, „Interdisciplinary Studies in Musicology” 8, 2009 (Theme Issue: Music between nature and culture), s. 119-136.

Przerembski Z.J., O fenomenie muzyki góralskiej na Podhalu, „Rocznik Podhalański” 14, 2019, s. $312-325$.

Przerembski Z.J., O sygnałowych funkcjach ludowych instrumentów muzycznych, [w:] Instrumenty muzyczne w tradycji ludowej i folkowej, red. Z.J. Przerembski, Zakopane 2011, s. 111-128.

Sroka S.A., Janosik: prawdziwa historia karpackiego zbójnika, Kraków 2004.

Strzelczyk J., Mity, podania i wierzenia dawnych Stowian, Poznań 2007.

Szlakiem kozła lubuskiego, zebr. i oprac. J. i M. Sobiescy, Kraków 1954.

Wielkopolskie śpiewki ludowe, oprac. J. Sobieska, Kraków 1957.

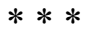

Zbigniew Jerzy Przerembski — profesor dr hab., kierownik Zakładu Muzykologii Systematycznej w Instytucie Muzykologii Uniwersytetu Wrocławskiego. Specjalizuje się w badaniu muzyki ludowej i dziejów muzyki tradycyjnej w Polsce i Europie, w tym zagadnień analizy i klasyfikacji, stylów, gatunków i form, instrumentów, praktyki wykonawczej. Jest autorem książek: Style i formy melodyczne polskich pieśni ludowych (1994), Dudy: dzieje instrumentu w kulturze staropolskiej (2006), Dudy: instrument mało znany polskim ludoznawcom (2007), Dudy: metamorfozy instrumentu w odrodzonej Polsce — od tradycji do folkloryzmu (2020). Pod jego redakcją ukazały się prace zbiorowe: Instrumenty muzyczne w tradycji ludowej i folkowej (2011), Rola orkiestr dętych w kulturze ludowej (2014), Etnomuzykologia na przełomie tysiacleci: historia, teoria, metodologia (2015), Taniec w kulturze (2017), Pieśni powszechne, [w:] J. Szymańska, Podlasie, cz. 3 i 4, seria: „Polska pieśń i muzyka ludowa: źródła i materiały” 5, red. L. Bielawski (2017), Z badań nad twórczościq literacka i artystyczna $w$ górskich regionach Europy (2019), Wesele: między przeszłościq a teraźniejszościa (2020). Opublikował ponad 200 tekstów naukowych i popularnonaukowych, zamieszczonych w specjalistycznych pracach zbiorowych i periodykach, encyklopediach muzycznych i powszechnych, polskich i zagranicznych, oraz witrynach internetowych. W Instytucie Sztuki PAN w Warszawie uczestniczy od wielu lat w pracach nad kolejnymi tomami regionalnymi z serii „Polska Pieśń i Muzyka Ludowa: źródła i materiały” (do tej pory ukazały się: Kaszuby, Warmia i Mazury, Lubelskie, Kujawy i Podlasie).

zbigniew.przerembski@uwr.edu.pl 